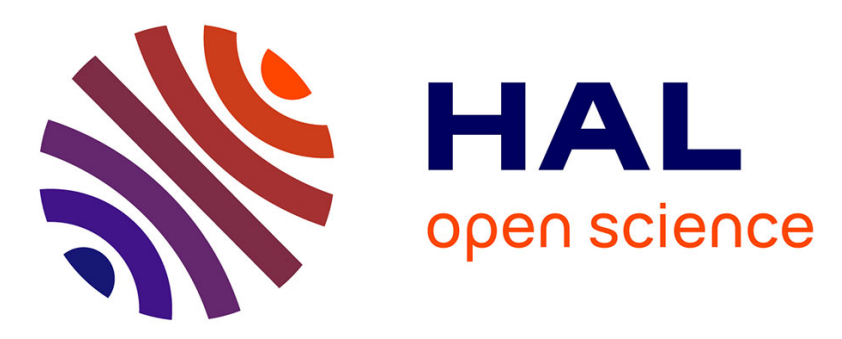

\title{
Uterine motor responses to an $\alpha$-adrenergic agonist (phenylephrine) in the ewe during oestrus and at the end of gestation \\ Marie-Jeanne Prud'Homme, Corinne Jamain
}

\section{- To cite this version:}

Marie-Jeanne Prud'Homme, Corinne Jamain. Uterine motor responses to an $\alpha$-adrenergic agonist (phenylephrine) in the ewe during oestrus and at the end of gestation. Reproduction Nutrition Développement, 1986, 26 (3), pp.827-839. hal-00898496

\section{HAL Id: hal-00898496 https://hal.science/hal-00898496}

Submitted on 1 Jan 1986

HAL is a multi-disciplinary open access archive for the deposit and dissemination of scientific research documents, whether they are published or not. The documents may come from teaching and research institutions in France or abroad, or from public or private research centers.
L'archive ouverte pluridisciplinaire HAL, est destinée au dépôt et à la diffusion de documents scientifiques de niveau recherche, publiés ou non, émanant des établissements d'enseignement et de recherche français ou étrangers, des laboratoires publics ou privés. 
Reprod. Nutr. Dévelop., 1986, 26 (3), 827-839.

\title{
Uterine motor responses \\ to an $\alpha$-adrenergic agonist (phenylephrine) in the ewe during oestrus and at the end of gestation
}

\author{
Marie-Jeanne PRUD'HOMME
}

with the technical assistance of Corinne JAMAIN

Physiologie de la Reproduction, I.N.R.A., Nouzilly, 37380 Monnaie, France.

Summary. The $x$-adrenergic activity of the myometrium was studied by recording the electromyographic activity (EMG) of the uterus in 4 conscious cyclic ewes during oestrus and in 8 conscious pregnant ewes during the last 6 days of gestation.

In the cyclic ewes, changes in intra-uterine pressure were recorded at the same time as the EMG. Motor responses to perfusions of phenylephrine, a specific $\alpha$-adrenergic agonist, were studied at three uterine sites. In the ewes in oestrus, uterine activity was stimulated at the three sites by perfusions with phenylephrine $(0.6,2.5,5$ or $10 \mu \mathrm{g} / \mathrm{kg} / \mathrm{min}$ ). The whole uterine horn was $\alpha$-adrenergic-responsive. The effect of the drug was dosedependent in that the uterine response increased with the dose and reached a plateau at $5 \mu \mathrm{g} / \mathrm{kg} / \mathrm{min}$.

In the late pregnant ewes, the motor responses to the perfusion of phenylephrine at $10 \mu \mathrm{g} / \mathrm{kg} / \mathrm{min}$ were studied at three uterine sites once a day during the last 6 days of gestation. Plasma levels of progesterone and total oestrogens were measured at the same time. Up to $48 \mathrm{~h}$ before parturition, the effect of phenylephrine depended on the uterine site. The drug had no or little effect at the tubal end of the horn. Phenylephrine stimulated uterine activity at the cervical end of the horn in at least $50 \%$ of the ewes. Thus, during this part of gestation, the $\alpha$-adrenergic sensitivity of the myometrium was greater at the cervical than at the tubal end of the uterine horn. Forty-eight hours before parturition, phenylephrine stimulated uterine activity at all three uterine sites in all the ewes. Thus, $\alpha$-adrenergic sensitivity developed over the uterine horn beginning $48 \mathrm{~h}$ before parturition at the same time that the oestrogen level increased.

\section{Introduction.}

Catecholamines modify uterine motility through stimulation of $\alpha$ and $\beta$ adrenergic receptors, the uterine $\alpha$-response being excitatory and the $\beta$-response inhibitory. Both $\alpha$ - and $\beta$-adrenergic receptors are found in the myometrium of cyclic ewes, as demonstrated by radioligand binding techniques (Rexroad, 1981) and in vivo by pharmacological techniques (Prud'homme, 1984). In pregnant or parturient ewes, only $\beta$-adrenergic receptors have been reported since stress, epinephrine and $\beta$-mimetics inhibit uterine motility (Naaktgeboren and Bontekoe, 1976 ; Quechon et al., 1982); the presence of these receptors has also been 
demonstrated recently by radioligand binding techniques (Crankshaw and Ruzycky, 1984). However, Maltier and Legrand (1984) have suggested that there may be an $\alpha$-adrenergic link in the preparation of the rat uterus for parturition. In this species, the number of $\alpha$-adrenergic receptors increases during the last $6 \mathrm{~h}$ of gestation, while the ratio of the concentration of epinephrine to that of norepinephrine in the uterus decreases. The consequence is that the myometrium becomes $\alpha$-adrenergic-sensitive at term (Maltier, Legrand and Corazza, 1984).

For this reason, we wished to determine the $\alpha$-adrenergic reactivity of the myometrium of late pregnant and parturient ewes. The aim of the present work was to study uterine motor responses to phenylephrine, a specific $\alpha$-adrenergic agonist. Plasma levels of progesterone and total oestrogens were measured at the same time. The responses to phenylephrine were also observed in ewes during oestrus.

\section{Material and methods.}

1) Animals and treatments. - Twelve ewes of the Préalpes du Sud breed weighing between 50 and $72 \mathrm{~kg}$ were used in this experiment.

Oestrus was induced in 4 of these ewes by placing sponges impregnated with $40 \mathrm{mg}$ of fluorogestone acetate in the vagina. After 14 days the sponges were removed and $400 \mathrm{IU}$ of pregnant mare's serum gonadotrophin were injected intramuscularly. The effects of phenylephrine were then studied, starting $48 \mathrm{~h}$ after the sponges were removed (at about the time that induced oestrus begins, Cognié et al., 1970), by perfusing physiological saline or phenylephrine (Sigma) into the jugular vein for $20 \mathrm{~min}$. The first perfusion was made with saline, the second with $0.6 \mu \mathrm{g}$ of phenylephrine $/ \mathrm{kg}$ of live weight $/ \mathrm{min}$, and the third, fourth and fifth perfusions with $2.5,5.0$ and $10.0 \mu \mathrm{g}$ of phenylephrine $/ \mathrm{kg}$ of live weight/min, respectively. Each of these perfusions was separated by a period of $2 \mathrm{~h}$. Thus, each ewe was perfused once with physiological saline and four times with increasing doses of phenylephrine.

The other 8 ewes were in late gestation. Phenylephrine $(10 \mu \mathrm{g} / \mathrm{kg}$ of live weight $/ \mathrm{min}$ ) was perfused daily for $20 \mathrm{~min}$ from day 138 of gestation. In two cases, the effects of phenylephrine were studied after intravenous administration of $50 \mathrm{mg}$ of phentolamine, an $\alpha$-blocker (Regitine, Ciba-Geigy). Lambing occurred between days 143 and 147 of gestation, which corresponds to the normal lambing period. Blood samples were taken by jugular venipuncture daily at days 138 and 139 of gestation and three times every $24 \mathrm{~h}$ from day 140 up through $24 \mathrm{~h}$ after parturition. Plasma levels of progesterone and of conjugated and unconjugated oestrone, which represent more than $80 \%$ of the total oestrogens in late pregnant ewes (Terqui, 1978), were measured by radioimmunoassay according to Yenikoye (1977) and Palmer and Terqui (1977), respectively.

2) Recording and measurement. - Uterine electromyographic activity (EMG) was recorded using bipolar $\mathrm{Ni}-\mathrm{Cr}$ electrodes implanted permanently in the myometrium according to the technique described by Garcia-Villar et al. 
(1982). The electrodes were placed at three sites in the uterine horn : the tubal end, the middle and the cervical end. Potential variations were amplified and recorded on paper by a pen-recorder (Beckman).

In the ewes in oestrus, intra-uterine pressure was recorded through an openend catheter placed in the uterine lumen at the time of electrode implantation and filled with saline. The frequency of EMG bursts per min was measured for $20 \mathrm{~min}$ before, during and after perfusion. Moreover, the EMG was integrated every $20 \mathrm{sec}$ using Latour's integrator circuit (1973). The response for each dose was determined by the total electrical activity integrated during $20 \mathrm{~min}$ of perfusion. The difference between this response and total electrical activity integrated during the preceding $20 \mathrm{~min}$ (control activity) was expressed as a percentage of control activity.

In the pregnant ewes, recordings were made on the gravid horn of the uterus. Since the phenylephrine treatment began on a fixed day of gestation (day 138) and lambing occurred 6 to 10 days later, only the data for the last 6 days of gestation for each animal were considered in determining the effect of phenylephrine.

This effect was quantified by calculating the percentage of animals in which the uterus was stimulated by drug administration.

\section{Results.}

1) Ewes in oestrus.

Activity pattern without perfusion or with saline perfusion. - The EMG pattern was similar in the 4 ewes with induced oestrus and consisted of bursts of three to twelve potentials lasting from 2 to $10 \mathrm{sec}$. The frequency of these bursts was between 2 and 3 per min, which was somewhat higher than during natural oestrus (Prud'homme and Pelé, 1984. However, the EMG was stable from the beginning of oestrus and up through $12 \mathrm{~h}$ after the LH peak, including the $9 \mathrm{~h}$ of recording. During perfusion with physiological saline, uterine activity was identical to this pattern (fig. 1a).

Activity pattern with phenylephrine perfusion. - At the four doses of phenylephrine used, the effect of the drug was characterized by an increase of EMG activity which was maximal during the first minutes of perfusion. This activity then decreased and became more regular with a lower frequency of bursts as perfusion progressed (fig. 1). At the lowest dose of $0.6 \mu \mathrm{g}$ of phenylephrine $/ \mathrm{kg} / \mathrm{min}$, EMG activity was maximal during the first $5 \mathrm{~min}$, with burst frequency reaching five per min. After the eighth minute, the activity decreased to a regular 2 to 3 bursts per min, identical with normal activity (fig. 1b). Therefore, the effect lasted a shorter time than the perfusion. Increasing doses of phenylephrine elicited increasing uterine response in both maximal activity at the onset of perfusion and in the frequency of bursts of regular activity later during perfusion. At doses of $2.5,5$ and $10 \mu \mathrm{g} / \mathrm{kg} / \mathrm{min}$ (figs. 1c, d, e), burst frequency was always higher than normal frequency over the whole duration of perfusion. 


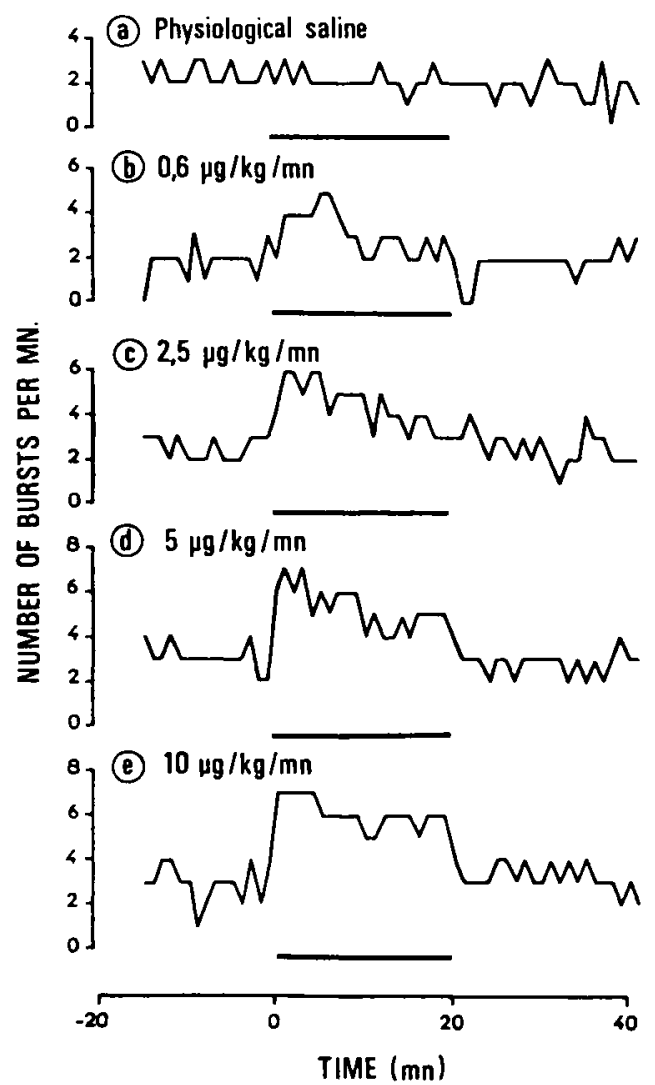

FIG. 1. - Effects of perfusion of physiological saline (a) or of phenylephrine at different doses (b, c, d, e) on the burst frequency of one ewe in oestrus. The horizontal bars represent the duration of perfusion.

The percentage of variation of the total EMG activity integrated during $20 \mathrm{~min}$ of perfusion increased with increasing doses up to $5 \mu \mathrm{g}$ of phenylephrine $/ \mathrm{kg} / \mathrm{min}$. The response did not increase above this dose : there was no significant difference between the percentage of variation in the activity calculated with a dose of 5 and that calculated with a dose of $10 \mu \mathrm{g} / \mathrm{kg} / \mathrm{min}$ (fig. 2).

The effect of perfusion with $10 \mu \mathrm{g} / \mathrm{kg} / \mathrm{min}$ on the electrical and mechanical activity of the myometrium is shown in figure 3. EMG activity increased at all three sites ; it was maximal during the first $5 \mathrm{~min}$ of perfusion, being continuous and thus corresponding to the mechanical activity of a muscle contracture. The muscle did not relax between contractions. After a slight decrease between the 5th and 6th min of perfusion, activity continued regularly at six bursts of EMG activity per minute (corresponding to six contractions) up to the end of perfusion. EMG activity decreased rapidly during the $2 \mathrm{~min}$ after perfusion had ended.Thereafter, it decreased at a slower rate, returning to normal between 15 and 20 min after the end of perfusion. 


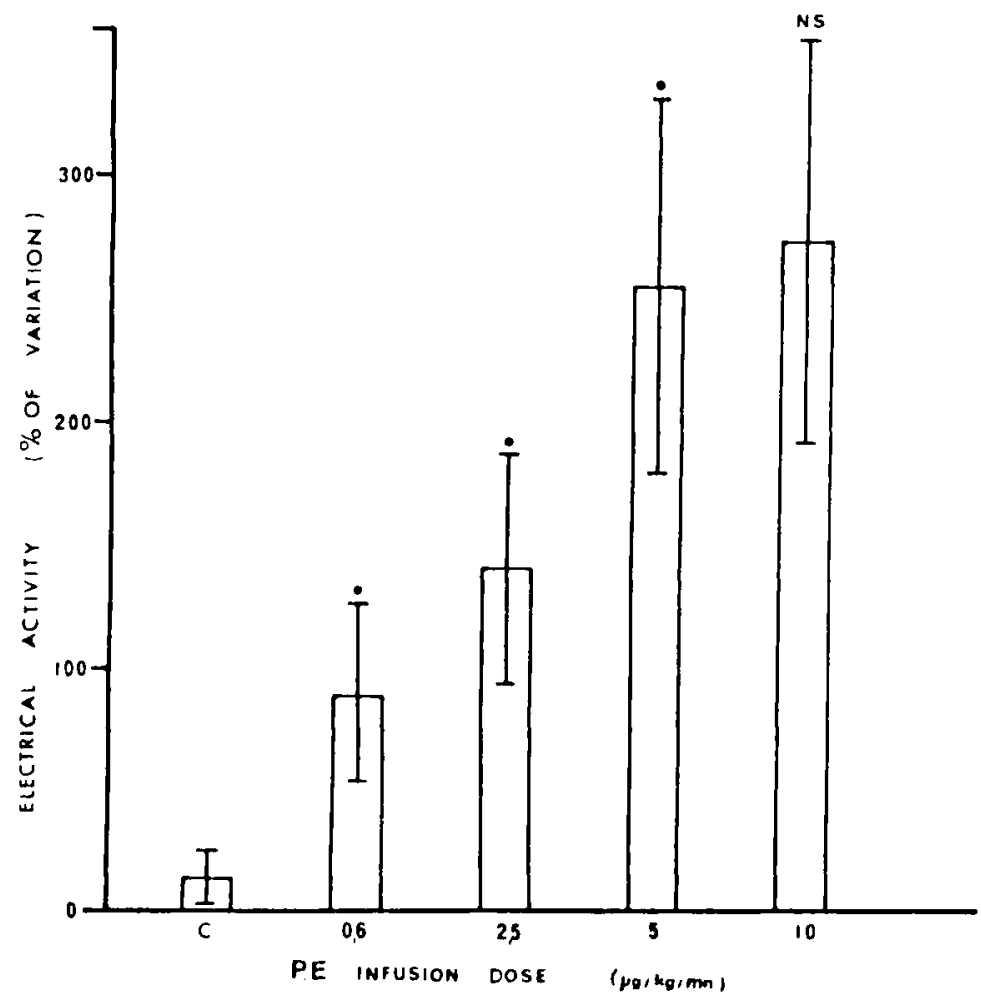

FIG. 2. - Dose-reponse effect of phenylephrine (PE) on EMG activity of the myometrium in 4 ewes in oestrus. The electrical activity is the total electrical activity integrated during the $20 \mathrm{~min}$ of perfusion of physiological saline $(C=$ control) or of each dose of phenylephrine. The percentage of variation of this electrical activity was determined in comparison with the total electrical activity integrated during the $20 \mathrm{~min}$ preceding the perfusion. Each value is the mean $\pm S E M$ of the percentage of variation for four perfusions per dose. Each dose was compared with the preceding one using Student's t-test. * : P< 0.05 ; NS : non-significant.

\section{2) Late pregnant ewes.}

Activity pattern without perfusion or with saline perfusion. - During the last days of gestation and up to $24 \mathrm{~h}$ before parturition, EMG activity showed active phases (about one per hour) that lasted 6 to $8 \mathrm{~min}$. After a transitory phase of several hours, the EMG pattern during the last $16-17 \mathrm{~h}$ was characterized by bursts of 40 to $50-\mathrm{sec}$ duration. The frequency of these bursts increased sharply from 4 every $10 \mathrm{~min}$ at $15 \mathrm{~h}$ before parturition to 8 every $10 \mathrm{~min}$ in the hour preceding lambing. Physiological saline did not modify this pattern.

Activity pattern during perfusion with $10 \mu \mathrm{g}$ of phenylephrine $/ \mathrm{kg} / \mathrm{min}$. - Up to $24 \mathrm{~h}$ before parturition, the perfusion of phenylephrine just after an active phase caused another period of activity in some cases. This stimulation began after a delay of 3 to $4 \mathrm{~min}$ and lasted 8 to $10 \mathrm{~min}$, that is for a shorter time than 

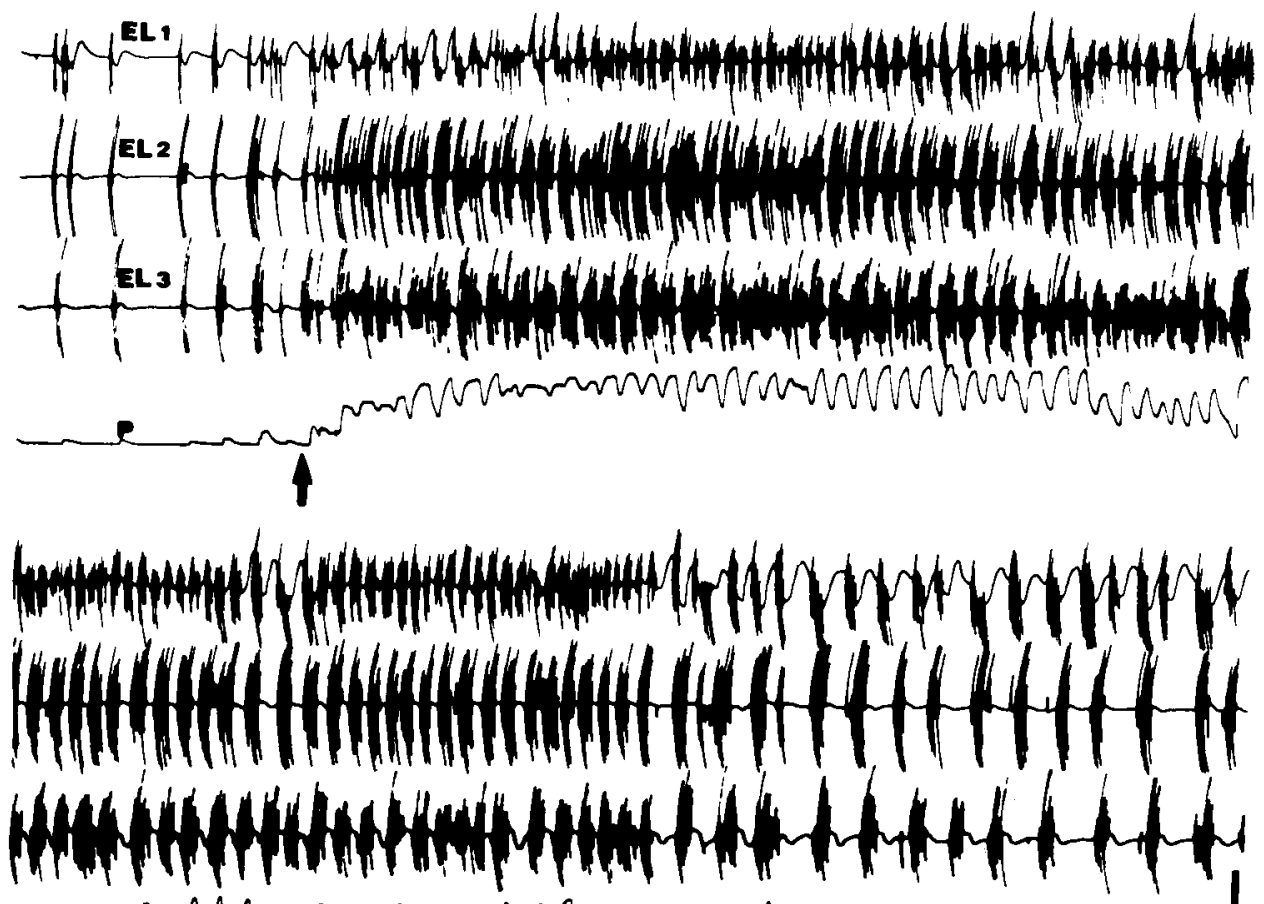

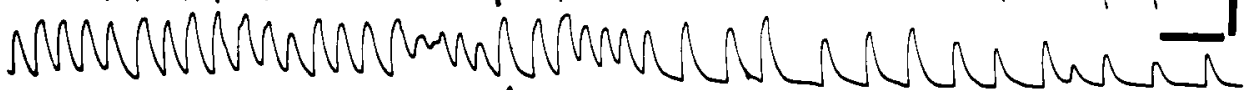

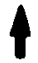

FIG. 3. - Effect of perfusion with $10 \mu \mathrm{g} / \mathrm{kg} / \mathrm{min}$ of phenylephrine on EMG activity of the myometrium recorded at three sites of the uterine horn and on intra-uterine pressure (P) in one ewe in oestrus. EL 1 : tubal end, EL 2 : middle, EL 3 : cervical end. 8 min separate the upper recordings from the lower ones. The arrows indicate the beginning and end of perfusion. Calibration : time, $30 \mathrm{sec}$; amplitude, $500 \mu \mathrm{V}, 30 \mathrm{mmHg}(P)$.

the perfusion (fig. 4). This response was suppressed by the administration of phentolamine, an $\alpha$-blocker.

However, phenylephrine did not act in all the ewes up to $48 \mathrm{~h}$ before parturition, and in one ewe in which it had an effect, phenylephrine did not always act at the three sites studied (fig. 5A). Six days and 5 days before parturition, there was no effect at the tubal end in any ewe; at the cervical end, there was an effect in $50 \%$ of the ewes. Between these two sites, an effect was observed for an intermediate percentage of cases. At 4 days before lambing, the number of ewes displaying stimulatory effects at the cervical end had increased $(6 / 8)$; however there was no effect at the tubal end. Three days before parturition responses were recorded at the tubal end in 3 out of 8 ewes. One day later, the effect was stimulatory in all the ewes at the three sites studied. During this time, the plasma progesterone level decreased while that of oestrogens increased (fig. 5B). There were high correlations between the number of ewes displaying stimulatory effects at the tubal, middle and cervical sites of the horn, respectively, and mean plasma 

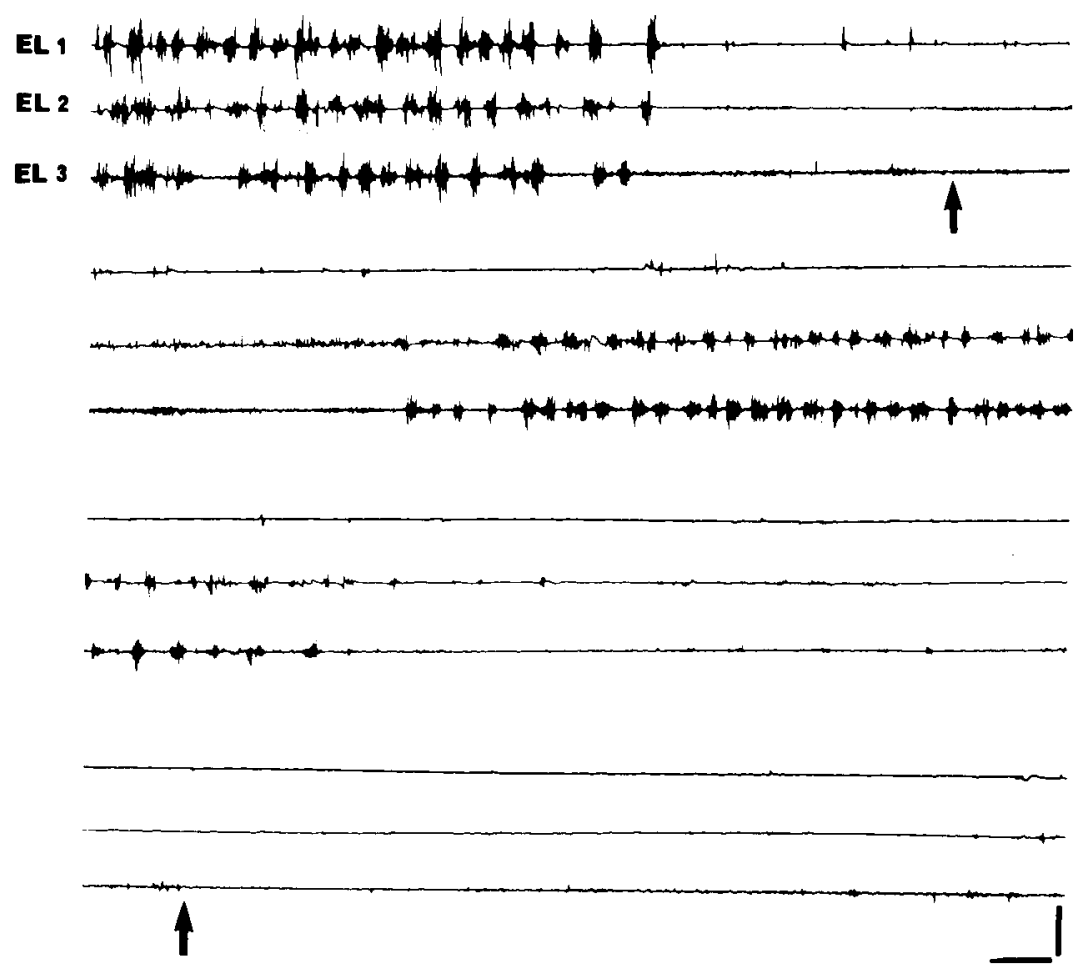

FIG. 4. - Effect of perfusion with $10 \mu \mathrm{g} / \mathrm{kg} / \mathrm{min}$ of pheny/ephrine on the EMG activity of the myometrium recorded at three sites of the gravid uterine horn in one ewe 4 days before parturition. EL 1 : tubal end, EL 2 : middle, EL 3 : cervical end. Lines 1, 2 and 3 succeed each other without interruption. The arrows indicate the beginning and end of perfusion. Calibration : time, $30 \mathrm{sec}$; amplitude, $500 \mu \mathrm{V}$.

hormone levels between 6 and 2 days before parturition : $-0.91,-0.95$ and -0.94 for progesterone $;+0.96,+0.99$ and +0.95 for oestrogens $;+0.99$, +0.99 and +0.94 for the oestrogens/progesterone ratio. Concerning the total time of phenylephrine-induced activity (table 1), we observed a gradient from the tubal to the cervical end and an increase of this time between 6 days and 2 days before parturition. During the last $24 \mathrm{~h}$ of gestation, uterine activity fluctuated and increased rapidly. The phenylephrine effect was not clear and did not exceed the fluctuations of spontaneous activity (fig. 6). Activity time during the first $10 \mathrm{~min}$ of perfusion was not different from that observed during the preceding $10 \mathrm{~min}(\mathrm{P}>0.05$; paired $t$-test). Therefore, it was not possible to demonstrate that phenylephrine had a stimulatory effect during the last hours of gestation.

\section{Discussion.}

This study demonstrates $\alpha$-adrenergic activity in the myometrium of ewes in oestrus and of those at the end of gestation. In both these physiological states,

Reproduction, Nutrition, Développement, $n^{\circ}$ 3-1986. -6 


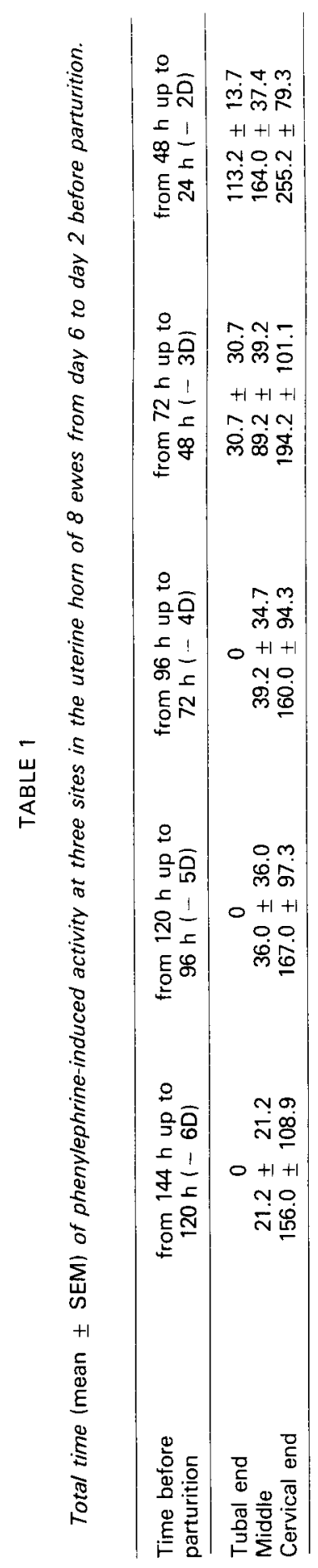



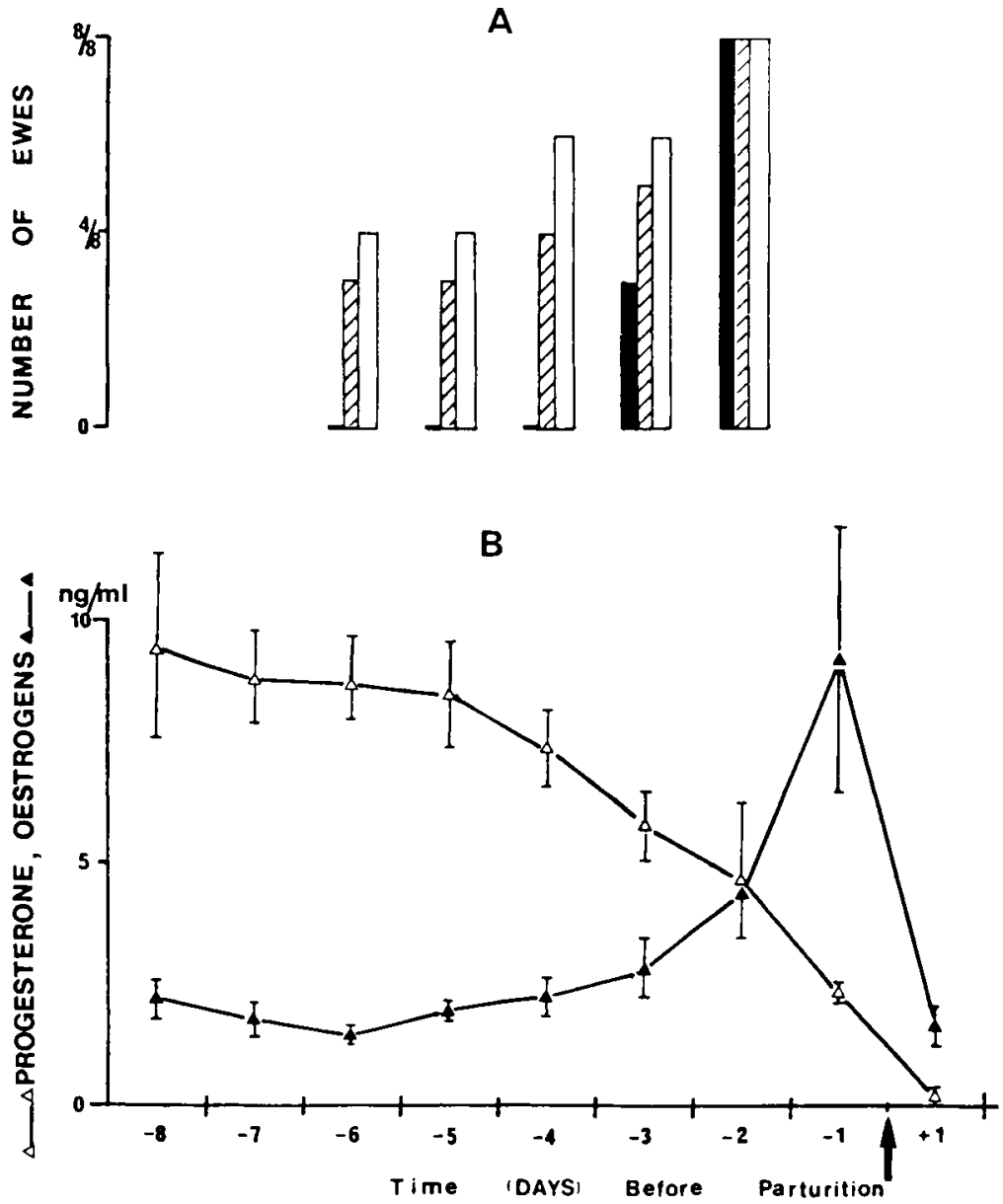

FIG. 5 A. - Proportion of ewes showing a stimulatory myometrial response to phenylephrine at three sites of the gravid uterine horn each day from day 6 to day 2 before parturition. Full columns : tubal end; hatched columns : middle; open columns : cervical end.

FIG. 5B. - Plasma concentrations of progesterone and total oestrogens before parturition. mean \pm SEM for 8 ewes.

the uterine electrical activity pattern, with or without the perfusion of physiological saline, corresponded to that previously described by Prud'homme and Bosc (1977), Toutain et al. (1983) and Prud'homme and Pelé (1984).

Uterine response to perfusion with phenylephrine was not constant during perfusion but reached a peak and then declined to a stable level after 8 to $10 \mathrm{~min}$. The frequency of bursts was then identical to that before perfusion for the lowest dose studied in ewes in oestrus $(0.6 \mu \mathrm{g} / \mathrm{kg} / \mathrm{min})$ and before perfusion for the single dose studied in pregnant ewes $(10 \mu \mathrm{g} / \mathrm{kg} / \mathrm{min})$. This frequency was higher than normal in the other cases. It can be supposed that the response peak corres- 

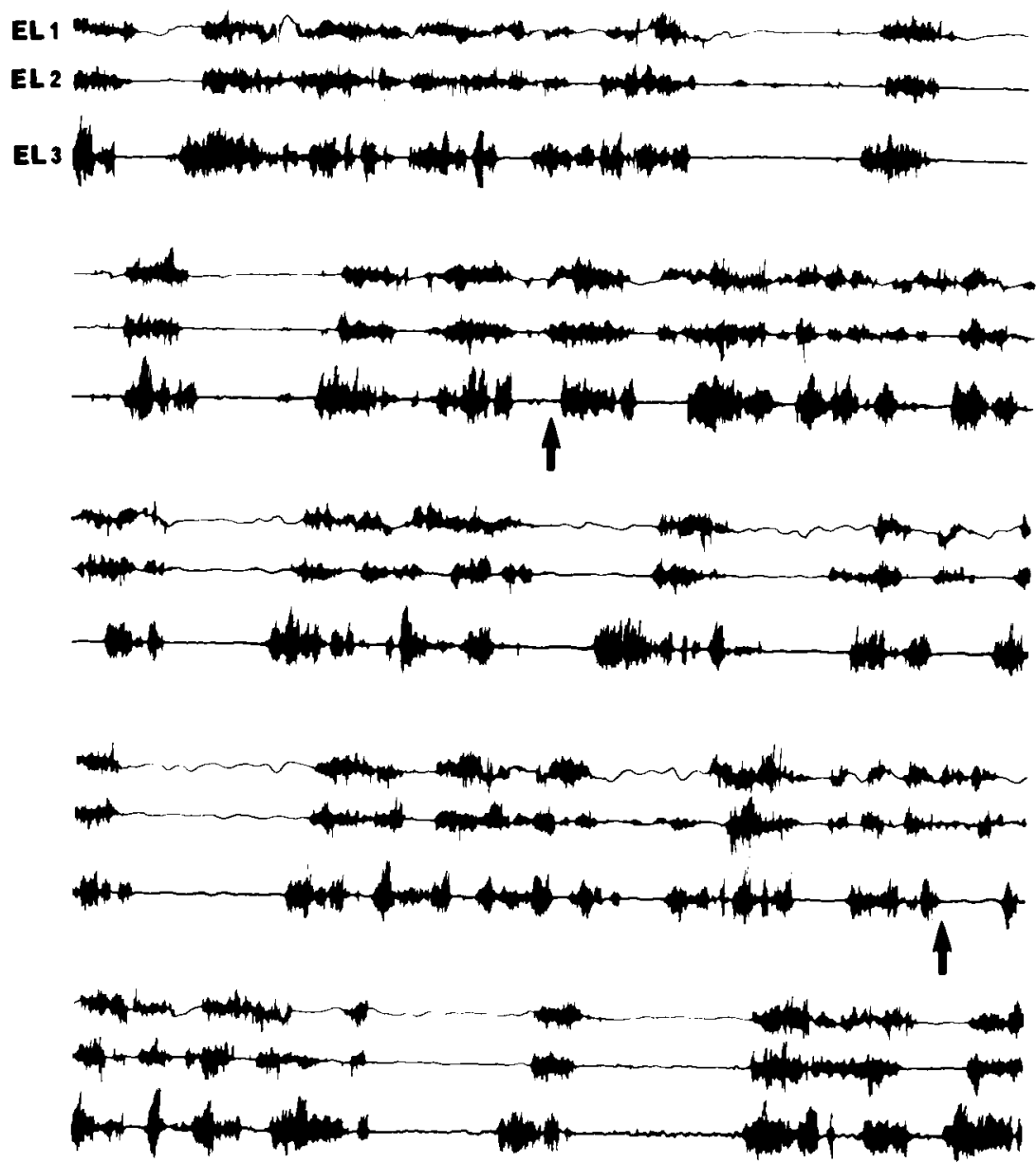

FIG. 6. - Effect of perfusion with $10 \mu \mathrm{g} / \mathrm{kg} / \mathrm{min}$ of phenylephrine on EMG activity of the myometrium at three sites of the gravid uterine horn in one ewe $4 \mathrm{~h}$ before parturition. EL 1: tubal end ; EL 2 : middle; EL 3 : cervical end. Lines 1, 2 and 3 succeed each other without interruption. The arrows indicate the beginning and end of perfusion. Calibration : time, 30 sec : amplitude, $500 \mu v$.

ponds to a peak of plasma phenylephrine concentration at the onset of perfusion before the drug was distributed into the different body compartments and before a balance was established between its elimination and its administration by perfusion.

Uterine response to phenylephrine in ewes in oestrus increased up to $5 \mu \mathrm{g} / \mathrm{kg} / \mathrm{min}$. Response at a dose of $10 \mu \mathrm{g} / \mathrm{kg} / \mathrm{min}$ was not significantly higher ; therefore maximal response was obtained with $5 \mu \mathrm{g} / \mathrm{kg} / \mathrm{min}$. This probably means that the dose was sufficient to saturate the receptors. 
Until 2 days before lambing, the percentage of pregnant ewes responding to the $\alpha$-adrenergic agonist never reached $100 \%$ and varied with the uterine site. Response was maximal at the cervical end. From these results, we may conclude that $\alpha$-adrenergic receptors have a concentration gradient increasing from the tubal to the cervical end of the horn. These results are in agreement with those reported earlier in oestrous ewes by Prud'homme (1984) who showed that there was an $\alpha$-effect over the whole uterine horn but that it was rot predominant at the tubal end. The phenylephrine effect increased from 6 days up to $24 \mathrm{~h}$ before parturition, while the progesterone level decreased and the oestrogen level increased. It is suggested that the $\alpha$-adrenergic sensitivity of the myometrium, and therefore probably the $\alpha$-adrenergic receptors, are hormone-dependent. We do not know if they increase with the decrease in progesterone or with the increase in oestrogens. These results agree with those of Marshall (1970). Uterine response to catecholamines in cats, rats and rabbits changes with the hormonal state : the response is stimulatory when the myometrium is oestrogen-dominated $(\alpha$-effect) and inhibitory when it is progesterone-dominated ( $\beta$-effect). The $\alpha$ effect might be explained by the results of Roberts et al. (1977) in rabbits; these authors concluded that oestrogens stimulate the synthesis of $\alpha$-adrenergic receptors. Hence, the increase of $\alpha$-adrenergic sensitivity in ewes at the end of gestation is probably more closely related to oestrogen increase, leading to higher uterine activity under the influence of catecholamines.

in our study, the $\alpha$-effect was not observed during labour. This may be due to a sharp decrease of the $\alpha$-adrenergic receptors or to a saturation and/or desensitization of the receptors under endogenous catecholamine influence. However, catecholamine concentration in the ewe myometrium is not higher at 145 days of gestation (i.e. approximately at term) than at 105 days (Sigger and Summers, 1984). These observations are not detailed enough to explain our results because this study did not concern the last hours preceding parturition and, hence, could not demonstrate any rapid changes which might have occurred during this period.

Reçu en mars 1985.

Accepté en mars 1986.

Acknowledgements. - The author wishes to thank D. André, T. Bridonneau and C. Fagu for the steroid radioimmunoassays, M. Terriot for the photographic reproduction, the secretary for typing the manuscript and R. Kilgour and D. Krehbiel for help with the English translation.

Résumé. Etude des réponses motrices de l'utérus à un agoniste $x$-adrénergique (Phényléphrine) chez la brebis pendant l'œestrus et à la fin de la gestation.

L'activité électromyographique (EMG) de l'utérus est enregistrée chez 4 brebis cycliques éveillées pendant l'œstrus et chez 8 brebis éveillées au cours des 6 derniers jours de la gestation. Chez les brebis cycliques, les variations de la pression intra-utérine sont enregistrées en même temps que l'EMG. Les réponses motrices à des perfusions de phényléphrine (un agoniste $\alpha$-adrénergique spécifique) sont étudiées en 3 points de la corne utérine. Chez les brebis en oestrus, l'activité utérine est stimulée par les 4 doses de phénylephrine utilisées $(0,6 ; 2,5 ; 5$ et $10 \mu \mathrm{g} / \mathrm{kg} / \mathrm{mn})$ au niveau des 3 points. Les réponses utérines croissent avec 
la dose jusqu'à $5 \mu \mathrm{g} / \mathrm{kg} / \mathrm{mn}$; la réponse n'augmente pas au delà de cette dose. Ces résultats montrent l'existence d'une sensibilité $\alpha$-adrénergique sur toute la corne utérine chez la brebis en cstrus. L'effet du traitement dépend de la dose administrée.

Chez les brebis en fin de gestation, les réponses motrices à des perfusions de $10 \mu \mathrm{g} / \mathrm{kg} / \mathrm{mn}$ de phényléphrine sont étudiées en 3 points de la corne utérine gravide une fois par jour au cours des 6 derniers jours de la gestation. Les niveaux plasmatiques de la progestérone et des cestrogènes totaux sont mesurés simultanément. Jusqu'à $48 \mathrm{~h}$ avant la parturition l'effet de la phényléphrine dépend du site utérin. II n'y a pas ou peu d'effet à l'extrémité tubaire de la corne. La phényléphrine stimule l'activité utérine à l'extrémité cervicale de la corne chez $50 \%$ au moins des brebis. Ces résultats démontrent que lors de cette période de la gestation, la sensibilité $\alpha$-adrénergique du myomètre augmente de l'extrémité tubaire vers l'extrémité cervicale de la corne utérine. $48 \mathrm{~h}$ avant la parturition la phényléphrine stimule l'activité utérine au niveau des 3 sites d'enregistrement sur toutes les brebis. Ces résultats démontrent que la sensibilité $\alpha$-adrénergique se développe sur toute la corne utérine gravide à partir de $48 \mathrm{~h}$ avant la mise-bas au moment où les ostrogènes augmentent.

\section{Références}

COGNIE Y., MARIANA J. C., THIMONIER J., 1970. Etude du moment d'ovulation chez la brebis normale ou traitée par un progestagène associé ou non à une injection de PMSG. Ann. Biol. anim. Bioch. Biophys., 10, 15-24.

CRANKSHAW D. J., RUZYCKY A. L., 1984. Characterization of putative $\beta$-adrenoreceptors in the myometrium of the pregnant ewe : correlation between the binding of $\left({ }^{3} \mathrm{H}\right)$-dihydroalprenolol and the inhibition of myometrial contractility in vitro. Biol. Reprod., 30, 609-618.

GARCIA-VILLAR R., TOUTAIN P. L., RUCKEBUSCH Y., 1982. Electromyographic evaluation of the spontaneous and drug-induced motility of the cervix in sheep. J. Pharmacol. Methods, 7, 8390.

LATOUR A., 1973. Un dispositif simple d'analyse quantitative de l'électromyograme intestinal chronique. Ann. Rech. vét., 4, 347-353.

MALTIER J. P., LEGRAND C., 1984. Caractérisation et analyse quantitative des récepteurs $\alpha$-adrénergiques dans le myomètre de la rate préparturiente. In : Période péri-ovulatoire. Coll. Soc. Fr. Etude Fert., Masson Ed, Paris, 234-235.

MALTIER J. P., LEGRAND C., CORAZZA S., 1984. Catécholamines et réactivité adrénergique du myomètre chez la rate pré-parturiente. J. Physiol. Paris, 79, $14 \mathrm{~A}$.

MARSHALL J. M., 1970. Adrenergic innervation of the female reproductive tract: anatomy, physiology and pharmacology. Rev. Physiol. Biochem. Pharmacol., 62, 6-67.

NAAKTGEBOREN C., BONTEKOE E. H. M., 1976. Vergleichend-geburtskundliche Betrachtungen und experimentelle Untersuchungen über psychosomatische Störungen der Schwangerschaft und des Gerburtsablaufes. Z. Tierzüchtg. Züchtgsbiol., 93, 264-320.

PALMER E., TEROUI M., 1977. The measurement of total plasma oestrogens during the follicular phase of the mare's oestrous cycle. Theriogenology, 7, 331-338.

PRUD'HOMME M. J., 1984. Etude des réponses motrices de l'utérus aux catécholamines chez la brebis sous différentes imprégnations stéroidiennes. Mise en évidence du rôle des catécholamines endogènes. Reprod. Nutr. Dévelop., 24, 21-32.

PRUD'HOMME M. J., BOSC M. J., 1977. Motricité utérine de la brebis, avant, pendant et après la parturition spontanée ou après traitement par la dexaméthasone. Ann. Biol anim. Bioch. Biophys., 17, 9-19.

PRUD'HOMME M. J., PELÉ B., 1984. Activité électromyographique de l'utérus chez la brebis pendant la saison sexuelle : comparaison de l'œstrus naturel et de l'œstrus induit par les progestagènes seuls ou avec une supplémentation de PMSG. Reprod. Nutr. Dévelop., 24, 33-44.

QUECHON M., TOUTAIN P. L., GARCIA-VILLAR R., 1982. Action tocolytique du clenbutérol et contrôle de la parturition chez la brebis. In Pharmacologie et toxicologie vétérinaire. Coll. 
I.N.R.A. 8, 211-214. $2^{\text {nd }}$ Congress of the european Assoc. vet. Pharmacol. Toxicol. I.N.R.A. Publ., Paris.

REXROAD C. E., 1981. Binding of dihydroalprenolol and dihydroergocryptine to sheep myometrium. Biol. Reprod., 24, 831-838.

ROBERTS J. M., INSEL P. A., GOLDFIEN R. D., GOLDFIEN A., $1977 . \quad x$-adrenoreceptors but not $\beta$-receptors increase in rabbit uterus with oestrogen. Nature, 270, 624-625.

SIGGER J. N., SUMMERS R. J., 1984. Catecholamine concentrations in the myometrium of the sheep during late pregnancy. Proc. austr. Physiol. Pharmacol. Soc., 15, 54 P.

TERQUI M., 1978. Contribution à l'étude des cestrogènes chez la brebis et la truie. Th. Doct. ès Sci. nat., Univ. Paris VI, $111 \mathrm{pp}$.

TOUTAIN P. L., GARCIA-VILLAR R., HANZEN C., RUCKEBUSCH Y., 1983 . Electrical and mechanical activity of the cervix in the ewe during pregnancy and parturition. $J$. Reprod. Fert., 68, 195-204.

YENIKOYE A., 1977. Etude quantitative de différences génétiques dans le taux de sécrétion de progestérone au cours du cycle cestral chez la génisse. Th. $3^{e}$ cycle, Univ. Paris VI. 53 pp. 